\title{
Adulteration and Contamination of Commercial Sap of Hymenaea Species
}

\author{
Katyuce de Souza Farias, ${ }^{1}$ Sarah Alves Auharek, ${ }^{2}$ \\ Andréa Luiza Cunha-Laura, ${ }^{2}$ Jeana Mara Escher de Souza, ${ }^{1}$ \\ Geraldo Alves Damasceno-Junior, ${ }^{3}$ Mônica Cristina Toffoli-Kadri, ${ }^{4}$ \\ Wander Fernando de Oliveira Filiú, ${ }^{5}$ Edson dos Anjos dos Santos, ${ }^{6}$ \\ Marilene Rodrigues Chang, ${ }^{7}$ and Carlos Alexandre Carollo ${ }^{1}$ \\ ${ }^{1}$ Laboratório de Produtos Naturais e Espectrometria de Massas, UFMS, Cidade Universitária, Campo Grande, MS, Brazil \\ ${ }^{2}$ Laboratório de Pesquisa em Bioensaios, UFMS, Cidade Universitária, Campo Grande, MS, Brazil \\ ${ }^{3}$ Laboratório de Botânica, UFMS, Cidade Universitária, Campo Grande, MS, Brazil \\ ${ }^{4}$ Laboratório de Biofisiofarmacologia, UFMS, Cidade Universitária, Campo Grande, MS, Brazil \\ ${ }^{5}$ Laboratório de Bioquímica Clínica, UFMS, Cidade Universitária, Campo Grande, MS, Brazil \\ ${ }^{6}$ Laboratório de Bioquímica, UFMS, Cidade Universitária, Campo Grande, MS, Brazil \\ ${ }^{7}$ Laboratório de Pesquisas Microbiológicas, UFMS, Cidade Universitária, Campo Grande, MS, Brazil \\ Correspondence should be addressed to Carlos Alexandre Carollo; carlos.carollo@ufms.br
}

Received 4 December 2016; Revised 18 January 2017; Accepted 31 January 2017; Published 20 February 2017

Academic Editor: Marco Leonti

Copyright (C) 2017 Katyuce de Souza Farias et al. This is an open access article distributed under the Creative Commons Attribution License, which permits unrestricted use, distribution, and reproduction in any medium, provided the original work is properly cited.

\begin{abstract}
The Hymenaea stigonocarpa and Hymenaea martiana species, commonly known as "jatobá," produce a sap which is extracted by perforation of the trunk and is commonly used in folk medicine as a tonic. For this study, the authenticity of commercial samples of jatobá was verified by the identification of the main compounds and multivariate analysis and contamination by microbial presence analysis. The acute toxicity of the authentic jatobá sap was also evaluated. The metabolites composition and multivariate analysis revealed that none of the commercial samples were authentic. In the microbiological contamination analysis, five of the six commercial samples showed positive cultures within the range of 1,700-100,000 CFU/mL and the authentic sap produced no signs of toxicity, and from a histological point of view, there was the maintenance of tissue integrity. In brief, the commercial samples were deemed inappropriate for consumption and represent a danger to the population.
\end{abstract}

\section{Introduction}

The herbal drugs used by the population are sold on the street and local markets where they are, in general, not appropriately identified or packaged [1], and this restrained relationship between trade and quality can directly affect the health of the population [2].

Zaroni et al. [3] have shown in a survey carried out in the south of Brazil that $79 \%$ of the medicinal plants produced in the region exhibit high counts of aerobic microorganisms, molds, and yeasts. Another study, about the quality of commercial samples of guaco (Mikania glomerata) in the central market and pharmacies of Belo Horizonte, Brazil, showed a huge difference in the concentration of coumarin (a chemical marker of this species), which can result in variations of the normal pharmacological activity [4]. In India, a study showed that $84 \%$ of the "churna" samples (a formulation widely used by the local population as an herbal medicine) contain mercury, lead, and cadmium higher than those considered as acceptable by the World Health Organization [5].

Developed countries are stricter in monitoring this sector. In an investigation on the quality of commercial dried spices and herbs sold in the UK, it was found that $96 \%$ of the 2,833 samples sold were within the quality standards required and that only $1.5 \%$ presented some form of the pathogenic agent, like Salmonella spp. [6]. 
TABLE 1: Identification and localization of the studied material.

\begin{tabular}{lcc}
\hline Code & Material (vegetal part) & Localization (place, state, country) \\
\hline Js-1 & Jatobá commercial (sap) & Campo Grande, MS, Brazil \\
Js-2 & Jatobá commercial (sap) & Campo Grande, MS, Brazil \\
Js-3 & Jatobá commercial (sap) & Campo Grande, MS, Brazil \\
Js-4 & Jatobá commercial (sap) & Campo Grande, MS, Brazil \\
Js-5 & Jatobá commercial (sap) & Campo Grande, MS, Brazil \\
Js-6 & Jatobá commercial (sap) & Campo Grande, MS, Brazil \\
Hm-1 & Hymenaea martiana (sap) & Serra do Amolar, MS, Brazil \\
Hs-1 & Hymenaea stigonocarpa (sap) & Serra do Amolar, MS, Brazil \\
Hs-2 & Hymenaea stigonocarpa (sap) & Serra do Amolar, MS, Brazil \\
Hm-sb1 & Hymenaea martiana (stem bark) & Serra do Amolar, MS, Brazil \\
Hs-sb1 & Hymenaea stigonocarpa (stem bark) & Serra do Amolar, MS, Brazil \\
Hs-sb2 & Hymenaea stigonocarpa (stem bark) & Serra do Amolar, MS, Brazil \\
\hline
\end{tabular}

Another factor that may influence the safety of medicinal plants is toxicity. Many traditional herbs are potentially dangerous $[7,8]$. It is common to find reports on ingestion or exposure to toxic plants throughout the literature, whether accidental or due to errors during the processing of the plant extracts. Vichova and Jahodar [9] reported a study performed in pediatric hospitals in the Czech Republic between 1996 and 2001. During this period there were 174 cases of accidental exposure to toxic species by patients from 0 to 18 years, where the group of 1 to 3 -year-olds was the most affected, with $42.3 \%$ of the cases. What stands out within the research is the fact that the identified toxic species are readily available, found in public parks, school yards, gardens, and inside homes.

The genus Hymenaea (Leguminosae) is distributed throughout India, Africa, Central America, and many parts of South America [10]. This genus is widely used in popular medicine, particularly for treating inflammations, rheumatisms, coughs, and anemia $[11,12]$.

The species Hymenaea have a particular use in folk medicine when the sap of the trunk is used as a tonic [13, 14]. Also, the stem bark of $H$. stigonocarpa has antidiarrhetic, gastroprotective and healing effect on gastric and duodenal ulcers $[15,16]$, as well as antitermitic and antioxidant effect [17]. Among the compounds identified in this species, the terpenes of the epi-labdanoid type, present in theresin, were highlighted [18]. The bark of $H$. martiana showed antioxidant activity and the presence of phenol compounds [19], in addition to antinociceptive, antiedematogenic, anti-inflammatory, and analgesic properties [20], and antimicrobial agents acting against Cryptococcus neoformans, Trichophyton rubrum, Trichophyton mentagrophytes, and Microsporum canis [21]. H. courbaril (also known as jatobá), a substitute for $H$. stigonocarpa and $H$. martiana, is also widely used to treat wounds, bronchitis, and stomach diseases [22].

Despite the widespread use of the species in folk medicine and the broad distribution, there are no studies in the literature which evaluate the quality controls of commercial sap or methods able to check their authenticity. Thus, the present study has evaluated commercial samples of jatobá sap concerning the presence of microbiological contamination, followed by authenticity tests, as well as the evaluation of acute toxicity of an authentic sap.

\section{Materials and Methods}

2.1. Acquisition and Processing of the Plant Material. Six samples of jatobá sap (Js-1 to Js-6) sold in Campo Grande, Mato Grosso do Sul, Brazil, were obtained. Authentic sap have been obtained from the $H$. martiana Hayne (named Hm-1) and the $H$. stigonocarpa Mart. Ex Hayne species (denominated Hs-1 and Hs-2). Authentic samples were collected in Serra do Amolar (Mato Grosso do Sul, Brazil) by perforating the trunk. Stem bark was also collected (named Hm-sb1 from H. martiana and Hs-sb1 and Hs-sb2 from H. stigonocarpa). Species were identified by Geraldo Alves Damasceno-Junior and vouchers of the plants were deposited at the CGMS Herbarium under the numbers 38077 and 38078, respectively. Table 1 shown the samples, places, and code identifications used during this work. Hm-sb1, Hs-sb1, and Hs-sb2 were extracted with boiling water for 30 minutes (decoction). They were then lyophilized, as were all of the evaluated samples. The samples were kept refrigerated until the beginning of the analyses. Since the chemical profiles of the control sap were similar and the H. stigonocarpa was the most commonly used, Hs-1 was selected for a toxicity analysis as well as used as a control sample during the microbiological contamination test.

2.2. Authenticity. The commercial and authentic samples were evaluated at the University of São Paulo, School of Pharmaceutical Sciences of Ribeirão Preto, using a highperformance liquid chromatograph coupled with a micrOTOF II high-resolution mass spectrometer (Bruker) (HPLC-MS) equipped with a C-18 column (Sigma-Aldrich, ODS-2, $5 \mathrm{um}, 4.6 \times 250 \mathrm{~mm}$ ). The method includes the use of water containing $1 \%$ acetic acid (phase A) and acetonitrile containing $1 \%$ acetic acid (phase B) with the following gradient: for three minutes, $3 \%$ of $\mathrm{B}$, followed by a gradient of $3-12 \%$ of B for $25 \mathrm{~min}, 12-16 \%$ of B for $20 \mathrm{~min}$, and $16-100 \%$ of $\mathrm{B}$ for three minutes. The column was washed and restabilized for seven minutes before the next injection. The flow used 
was $1 \mathrm{~mL} / \mathrm{min}$. All samples were injected in a random order and the same concentration of $1 \mathrm{mg} / \mathrm{mL}$. MS spectra were acquired in positive mode and for the metabolomic analysis; the mass signals obtained from raw data files were extracted and aligned within the metAlign software program, with a final alignment of 5592 mass signals. Subsequently, the signals belonging to the same molecules, isotopes, fragments, and adducts, were regrouped using the MSClust software, resulting in 67 reconstructed metabolites. The molecular formulas of the major compounds were determined by peaks obtained by the mass spectrometer, taking into account the elements $\mathrm{C}, \mathrm{H}, \mathrm{O}$, and $\mathrm{N}$, the error being equal to or less than $5 \mathrm{ppm}$. The UV spectrum also characterized the compounds. Catechin and quercetin were identified through comparison with the authenticity standard (Sigma). Finally, the data was analyzed in Metaboanalyst 3.0 platform using Principal Component Analysis (PCA) and Heatmap. For PCA, data was $\log$ average transformed. For Heatmap, dispersion profile of the compounds and hierarchical clustering was organized using Euclidean distance, Ward clustering algorithm, and the top 40 metabolites selected by ANOVA $(p \leq 0.05)$.

2.3. Microbiological Evaluation. The methodology was in accordance with the United States Pharmacopeia [23] with minor modifications. Enrichment broths and selective media were used to research the viable microorganism count as well as for the identification of Salmonella sp., Escherichia coli, Staphylococcus aureus, Pseudomonas aeruginosa, and Candida albicans [24]. Every procedure was carried out aseptically and in triplicate in a biosafety cabinet. For the counting of the colony forming unit (CFU) an automated colony counter was used (model Q295B) (Quimis, Brazil), and the data was expressed as a mean average \pm standard deviation. The analysis following the recommendations set out by the World Health Organization [25].

2.4. Acute Toxicity. 45 Wistar rats of the species Rattus norvegicus were acquired from the animal facility of the Federal University of Mato Grosso do Sul (23 males and 22 females) with an average weight of $283 \pm 13$ grams. The animals underwent an adaptation period of 10 days, housed throughout the experiment in plastic cages equipped with beds of selected sawdust, with a light/dark cycle of 12 hours, with water and food at libitum. The animals were divided into four groups. The doses were administered using intragastric gavages in amounts of 1000,2500 , and $5000 \mathrm{mg} / \mathrm{kg}$ of the sample Hs-1. The control group received only water. The acute toxicity protocol was followed according to the recommendations of the Organization for Economic Cooperation and Development [26] and those of the specific resolution of the National Agency for Sanitary Surveillance [27]. All procedures and protocols followed approved guidelines for the ethical treatment of animals, according to the Ethics Committee in Animal Experimentation from the Federal University of Mato Grosso do Sul (Protocol \# 460/2012).

After the administration the different doses of jatobá sap, the animals were evaluated in the first half-hour and then two hours after the administration of the intragastric gavages samples and then every twelve hours for 14 days. The activity and coordination of the motor system and reflexes and the activity of the central and autonomous nervous systems such as general activity, sensory analysis (vocal tremor, irritability, reflex headset, touch response, response to tail pinch and corneal reflex), psychomotor analysis (contortion, position of the hind, righting reflex, body tone, and grip strength), analysis of the central nervous system (tremors, convulsions, tail erection, sedation, anaesthesia, and ataxia), and analysis of the autonomic nervous system (ptosis, presence of lacrimation, urination, defecation, cyanosis, and hypothermia) were evaluated. Differences were observed in body weight and food and water consumption before and after the experiment.

After the 14-day period, the animals were anesthetized with a ketamine-xylazine solution and then euthanized. The bowel was displaced and the aorta exposed to collect blood in two tubes (one containing an anticoagulant to determine the hematological parameters and one without for the extraction of serum and to determine the biochemical parameters). Subsequently, the kidneys and liver were removed, weighed, evaluated macroscopically, and processed for histopathological analysis. In brief, representative and extracted fragments were fixed using Bouin's solution. Once fixed, the tissue fragments were dehydrated, cleared, and embedded in paraffin wax. The samples were cut into $5 \mu \mathrm{m}$ thick sections and stained with haematoxylin-eosin for histological analyses.

2.5. Biochemical and Hematological Parameters. For the analysis of hematological parameters, the values of erythrocytes, leukocytes, platelets, hemoglobin, hematocrit, mean corpuscular volume (MCV), mean corpuscular hemoglobin $(\mathrm{MCH})$, and mean corpuscular hemoglobin concentration $(\mathrm{MCHC})$ were measured using an automated hematology analyzer model Sp-100i (SYSMEX, Kobe, Japan). The differential leukocyte count was performed on each device and confirmed in blood smears stained with May-GrunwaldGiemsa (100 cells analyzed and counted in each smear). For the biochemical analysis, blood samples were centrifuged at $1026 \times \mathrm{g}$ and the levels of glucose, urea, creatinine, alanine aminotransferase (ALT) and aspartate aminotransferase (AST), amylase, and lipase were determined. The tests were performed at the Clinical Laboratory of the University Hospital of the Federal University of Mato Grosso do Sul using an automated analyzer (brand COBAS 6000, Switzerland). All analyses were performed by monitoring of the control serum provided by the Excellence Program of Medical Laboratories (PELM) of Controlab, Brazilian Society of Clinical Pathology, Rio de Janeiro, and the control serum from the College of American Pathologists, Northfield, IL, USA.

2.6. Histomorphometry of the Liver and Kidney. The individual volume of the hepatocytes was obtained from their nuclear volume and the proportion between nucleus and cytoplasm. To calculate these proportions, a 540-point square lattice was placed over the sectioned materials at $1000 \mathrm{x}$ magnification. At least four thousand points of hepatocytes were counted for each animal ( $n=8$ in each group). Because the hepatocyte nucleus in rats is spherical, its nucleus volume was obtained to our knowledge of the mean nuclear diameter. For this purpose, the diameters of forty nuclei were measured 


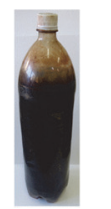

Js-1

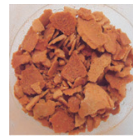

Js-1

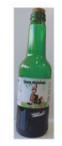

Js-2

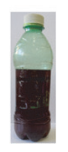

Js-3

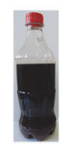

Js-4

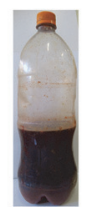

Js-5

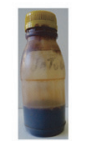

Js-6

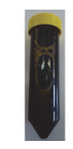

Hm-1

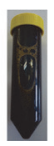

Hs-1

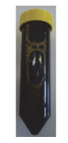

Hs-2

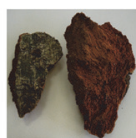

Hm-sb1

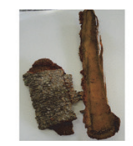

Hs-sb1

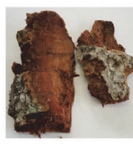

Hs-sb2

(a)

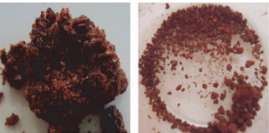

Js-2

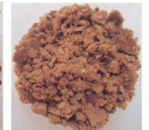

Js-4

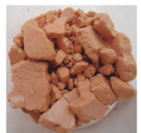

Js-5

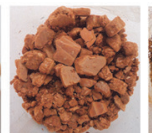

Js-6

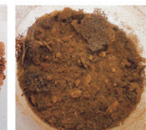

$\mathrm{Hm}-1$

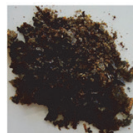

Hs-1

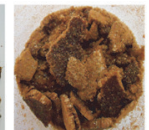

Hs-2

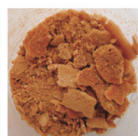

Hm-sbl

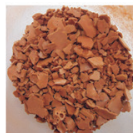

Hs-sb1

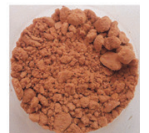

Hs-sb2

(b)

FIGURE 1: (a) Samples in the packaging in which they were acquired and (b) dry residues obtained after lyophilization. The authentic sap is listed as Hm-1, Hs-1, and Hs-2 and those obtained by decoction of the stem bark as Hm-sb1, Hs-sb1, and Hs-sb2. Commercial samples are listed as Js-1-Js-6. Samples Hs-1, Hs-2, Hs-sb1, and Hs-sb2 belong to H. stigonocarpa and Hm-1 and Hm-sb1 to H. martiana.

for each animal. Hepatocyte nuclear volume was expressed in $\mu \mathrm{m}^{3}$ and obtained using the formula $4 / 3 \pi r 3$, where $r=$ nuclear diameter/2 [28]. In the kidney, the same analyses were performed, and the nuclear volume of the cells of the proximal convoluted tubule was estimated. Moreover, the diameters of the renal and glomerular corpuscles were also measured.

2.7. Statistical Analysis. The results of the acute toxicity evaluation, as well as the biochemical, hematological, and histological parameters, were expressed as a mean average \pm standard deviation. A variance analysis (ANOVA) was used, of a route followed by Tukey's multiple range test using the GraphPad Prism $4^{\circledR}$ software. The values for $p$ less than 0.05 were considered significant.

\section{Results and Discussion}

An important part of the quality control is the confirmation of authenticity. Some species, even though being similar taxonomically, may have different pharmacological and toxicological effects [29].

Regarding organoleptic traits, the samples exhibited visual and yields differences (Figure 1): 1.47\% (Js-1), 1.48\% (Js2), $0.52 \%$ (Js-3), $1.21 \%$ (Js-4), 2.24\% (Js-5), 1.11\% (Js-6), 2.92\% (Hm-1), 6.84\% (Hs-1), 4.06\% (Hs-2), 4.75\% (Hm-sb1), 2.17\% (Hs-sb1), and 3.54\% (Hs-sb2).

Even the dried mass of control samples (Hm-1, Hs1, and Hs-2) was inconstant, which may reflect different concentrations of compounds. This variation may be related to the age of the plant species or other edaphoclimatic factors. Specific studies are required to determine the best parameters for the collecting of the sap. The commercial samples (Js-1, Js2 , Js-3, Js-4, Js-5, and Js-6) exhibited significantly lower values than the control ( $t$-test $p$ less than 0.05$)$, which may suggest dilution.

The quality control of the plant samples using traditional techniques is not always a suitable alternative because plant species have various phytochemicals that act together. Thus, chromatographic fingerprinting may be able to describe the complexity of the plant extract [30-32] and help characterize those plant extracts that do not have any preestablished monographs.

The chromatograms of the samples acquired by HPLCMS are shown in Figure 2.

Among the compounds found in the control sap and jatobá stem bark, the main components were flavonoids and procyanidins, characterized by the molecular formula and the UV spectrum and compared to referential data. Despite the lack of studies performed on jatobá sap, these classes of compounds have been described in the wood bark of this plant species [17]. About the compounds found in the bark used for the present study; only procyanidins have been previously described in the literature on $H$. courbaril, the substitute species for $H$. stigonocarpa [33].

There is a clear distinction between commercial samples and controls sap. Considering that there are no Pharmacopeia monographs of this plant species, the authenticity analysis took into consideration the main peaks of authentic samples and discriminant analysis by PCA, Biplot (Figure 3), and Heatmap (Figure 4). The main peaks of the samples from $H$. stigonocarpa Hs-1 and Hs-sbl are shown in Table 2.

PCA, Biplot, and Heatmap analysis reveal the presence of two main groups. After evaluation and comparison, the main peaks characteristic of $\mathrm{Hm}-1$, Hs-1, and Hs-2 are the compounds 1, 11, 14, 23, 26, 33, 37, and 50 (Table 2) and found no resemblance to the commercial samples. Among the commercial and stem bark samples, two groups were formed one by Js-2, Js-3, and Js- 6 pooled separately and other by Js-1, Js-4, Js-5, Hm-sb1, Hs-sb1, and Hs-sb2 (Figure 4). The main peaks for these groups were $17,19,24,25,30$, and 41. The separation of these groups could be caused by a different dilution of commercial samples, as observed in mass spectrometry chromatograms (Figure 2).

The PCA (Figure 3(a)) represents $59.7 \%$ of the variability of the data, where the components 1 and 2 represent $40.3 \%$ and $19.4 \%$, respectively. The Heatmap and Biplot showed clearly a separation based on metabolites of the analyzed 
TABLE 2: The major compounds present in the sap of Hymenaea stigonocarpa (Hs-1) and stem bark (Hs-sb1).

\begin{tabular}{|c|c|c|c|c|c|c|}
\hline Peak & Time (min) & Compound name & $\mathrm{M} / \mathrm{S}(\mathrm{m} / z)$ & Molecular formula & Error (ppm) & Sap/stem bark \\
\hline 1 & 3.1 & Unknown & 297.0611 & $\mathrm{C}_{13} \mathrm{H}_{12} \mathrm{O}_{8}$ & 1 & Sap \\
\hline 2 & 5.2 & Unknown & 269.0021 & - & & Stem bark \\
\hline 3 & 11.0 & Unknown & 329.0872 & $\mathrm{C}_{14} \mathrm{H}_{16} \mathrm{O}_{9}$ & 1 & Sap \\
\hline 4 & 19.4 & $\begin{array}{l}\text { Procyanidin II } \\
\text { Derivative }\end{array}$ & $\begin{array}{l}579.1475 \\
579.1491\end{array}$ & $\mathrm{C}_{30} \mathrm{H}_{26} \mathrm{O}_{12}$ & $\begin{array}{l}5 \\
2\end{array}$ & $\begin{array}{c}\text { Sap } \\
\text { Stem bark }\end{array}$ \\
\hline 5 & 21.5 & $\begin{array}{c}\text { Procyanidin II } \\
\text { Derivative glycosyl }\end{array}$ & 725.2069 & $\mathrm{C}_{36} \mathrm{H}_{36} \mathrm{O}_{16}$ & 3 & Stem bark \\
\hline 6 & 21.1 & Flavan-3-ol derivative & 275.0910 & $\mathrm{C}_{15} \mathrm{H}_{14} \mathrm{O}_{5}$ & 4 & Sap \\
\hline 7 & 22.5 & Catechin & $\begin{array}{l}291.0863 \\
291.0864\end{array}$ & $\mathrm{C}_{15} \mathrm{H}_{14} \mathrm{O}_{6}$ & $\begin{array}{l}2 \\
2\end{array}$ & $\begin{array}{c}\text { Sap } \\
\text { Stem bark }\end{array}$ \\
\hline 8 & 22.9 & $\begin{array}{l}\text { Procyanidin III } \\
\text { Derivative }\end{array}$ & 867.2103 & $\mathrm{C}_{45} \mathrm{H}_{38} \mathrm{O}_{18}$ & 4 & Stem bark \\
\hline 9 & 24.9 & $\begin{array}{l}\text { Procyanidin II } \\
\text { Derivative }\end{array}$ & 725.2074 & $\mathrm{C}_{36} \mathrm{H}_{36} \mathrm{O}_{16}$ & 2 & Stem bark \\
\hline 10 & 26.2 & Unknown & 453.2501 & $\mathrm{C}_{24} \mathrm{H}_{36} \mathrm{O}_{8}$ & 3 & Sap \\
\hline 11 & 26.2 & Unknown & 209.1152 & - & & Sap \\
\hline 12 & 27.1 & Flavonoid Derivative & 285.0749 & $\mathrm{C}_{16} \mathrm{H}_{12} \mathrm{O}_{5}$ & 5 & Sap \\
\hline 13 & 27.2 & Unknown & 453.2487 & $\mathrm{C}_{24} \mathrm{H}_{36} \mathrm{O}_{8}$ & 1 & Sap \\
\hline 14 & 27.2 & Unknown & 209.1152 & - & & Sap \\
\hline 15 & 28.5 & Unknown & 209.0878 & - & & Sap \\
\hline 16 & 28.5 & $\begin{array}{l}\text { Procyanidin II } \\
\text { Derivative }\end{array}$ & 563.1534 & $\mathrm{C}_{30} \mathrm{H}_{26} \mathrm{O}_{11}$ & 2 & Sap \\
\hline 17 & 28.8 & $\begin{array}{l}\text { Procyanidin II } \\
\text { Derivative }\end{array}$ & 579.1496 & $\mathrm{C}_{30} \mathrm{H}_{26} \mathrm{O}_{12}$ & 2 & Stem bark \\
\hline 18 & 30.0 & Flavonol Glycosyl & 479.1188 & $\mathrm{C}_{22} \mathrm{H}_{22} \mathrm{O}_{12}$ & 1 & Sap \\
\hline 19 & 30.4 & Unknown & 739.1850 & $\mathrm{C}_{43} \mathrm{H}_{30} \mathrm{O}_{12}$ & 5 & Stem bark \\
\hline 20 & 30.9 & $\begin{array}{l}\text { Procyanidin II } \\
\text { Derivative }\end{array}$ & 563.1553 & $\mathrm{C}_{30} \mathrm{H}_{26} \mathrm{O}_{11}$ & 1 & Sap \\
\hline 21 & 31.1 & Epicatechin & $\begin{array}{l}291.0858 \\
291.0857\end{array}$ & $\mathrm{C}_{15} \mathrm{H}_{14} \mathrm{O}_{6}$ & $\begin{array}{l}4 \\
4\end{array}$ & $\begin{array}{c}\text { Sap } \\
\text { Stem bark }\end{array}$ \\
\hline 22 & 32.1 & Flavonoid Derivative & 289.0698 & $\mathrm{C}_{15} \mathrm{H}_{12} \mathrm{O}_{6}$ & 5 & Sap \\
\hline 23 & 32.1 & Unknown & 271.0599 & $\mathrm{C}_{15} \mathrm{H}_{10} \mathrm{O}_{5}$ & 3 & Sap \\
\hline 24 & 32.3 & $\begin{array}{l}\text { Procyanidin II } \\
\text { Derivative }\end{array}$ & 723.1900 & $\mathrm{C}_{36} \mathrm{H}_{34} \mathrm{O}_{16}$ & 4 & Stem bark \\
\hline 25 & 32.9 & Unknown & 739.1832 & $\mathrm{C}_{43} \mathrm{H}_{30} \mathrm{O}_{12}$ & 3 & Stem bark \\
\hline 26 & 32.9 & Flavanonol Derivative & 319.0801 & $\mathrm{C}_{16} \mathrm{H}_{14} \mathrm{O}_{7}$ & 5 & Sap \\
\hline 27 & 35.3 & $\begin{array}{l}\text { Procyanidin II } \\
\text { Derivative }\end{array}$ & 563.1541 & $\mathrm{C}_{30} \mathrm{H}_{26} \mathrm{O}_{11}$ & 2 & Sap \\
\hline 28 & 35.5 & $\begin{array}{l}\text { Procyanidin II } \\
\text { Derivative }\end{array}$ & 723.1904 & $\mathrm{C}_{36} \mathrm{H}_{34} \mathrm{O}_{16}$ & 3 & Stem bark \\
\hline 29 & 36.4 & Unknown & 739.1847 & $\mathrm{C}_{43} \mathrm{H}_{30} \mathrm{O}_{12}$ & 4 & Stem bark \\
\hline 30 & 36.7 & $\begin{array}{l}\text { Procyanidin III } \\
\text { Derivative }\end{array}$ & 867.2092 & $\mathrm{C}_{45} \mathrm{H}_{38} \mathrm{O}_{18}$ & 5 & Stem bark \\
\hline 31 & 37.9 & $\begin{array}{l}\text { Procyanidin II } \\
\text { Derivative }\end{array}$ & 563.1541 & $\mathrm{C}_{30} \mathrm{H}_{26} \mathrm{O}_{11}$ & 3 & Sap \\
\hline 32 & 38.9 & $\begin{array}{l}\text { Procyanidin II } \\
\text { Derivative }\end{array}$ & 723.1901 & $\mathrm{C}_{36} \mathrm{H}_{34} \mathrm{O}_{16}$ & 4 & Stem bark \\
\hline 33 & 40.2 & Flavanonol Derivative & 319.0802 & $\mathrm{C}_{16} \mathrm{H}_{14} \mathrm{O}_{7}$ & 5 & Sap \\
\hline 34 & 40.5 & Unknown & 277.1060 & $\mathrm{C}_{15} \mathrm{H}_{16} \mathrm{O}_{5}$ & 6 & Sap \\
\hline 35 & 40.9 & Flavone Derivative & 285.0753 & $\mathrm{C}_{16} \mathrm{H}_{12} \mathrm{O}_{5}$ & 5 & Sap \\
\hline 36 & 41.2 & $\begin{array}{l}\text { Flavan-3-ol } \\
\text { Derivative }\end{array}$ & 305.1019 & $\mathrm{C}_{16} \mathrm{H}_{16} \mathrm{O}_{6}$ & 2 & Sap \\
\hline
\end{tabular}


TABLE 2: Continued.

\begin{tabular}{|c|c|c|c|c|c|c|}
\hline Peak & Time $(\min )$ & Compound name & $\mathrm{M} / \mathrm{S}(m / z)$ & Molecular formula & Error (ppm) & Sap/stem bark \\
\hline 37 & 41.2 & Unknown & 153.0534 & - & & Sap \\
\hline 38 & 41.7 & $\begin{array}{l}\text { Procyanidin II } \\
\text { Derivative }\end{array}$ & 563.1542 & $\mathrm{C}_{30} \mathrm{H}_{26} \mathrm{O}_{11}$ & 3 & Sap \\
\hline 39 & 41.9 & $\begin{array}{l}\text { Procyanidin II } \\
\text { Derivative }\end{array}$ & 723.1911 & $\mathrm{C}_{36} \mathrm{H}_{34} \mathrm{O}_{16}$ & 2 & Stem bark \\
\hline 40 & 42.4 & $\begin{array}{l}\text { Procyanidin II } \\
\text { Derivative }\end{array}$ & 563.1553 & $\mathrm{C}_{30} \mathrm{H}_{26} \mathrm{O}_{11}$ & 1 & Sap \\
\hline 41 & 42.9 & Unknown & 739.1844 & $\mathrm{C}_{43} \mathrm{H}_{30} \mathrm{O}_{12}$ & 4 & Stem bark \\
\hline 42 & 43.6 & Unknown & 739.1851 & $\mathrm{C}_{43} \mathrm{H}_{30} \mathrm{O}_{12}$ & 5 & Stem bark \\
\hline 43 & 44.8 & $\begin{array}{l}\text { Procyanidin II } \\
\text { Derivative }\end{array}$ & 563.1533 & $\mathrm{C}_{30} \mathrm{H}_{26} \mathrm{O}_{11}$ & 4 & Sap \\
\hline 44 & 47.3 & Unknown & $\begin{array}{l}249.1167 \\
249.1149\end{array}$ & - & - & $\begin{array}{c}\text { Sap } \\
\text { Stem bark }\end{array}$ \\
\hline 45 & 47.4 & $\begin{array}{l}\text { Procyanidin II } \\
\text { Derivative }\end{array}$ & 563.1545 & $\mathrm{C}_{30} \mathrm{H}_{26} \mathrm{O}_{11}$ & 2 & Sap \\
\hline 46 & 47.7 & Flavanonol Derivative & 305.0647 & $\mathrm{C}_{15} \mathrm{H}_{12} \mathrm{O}_{7}$ & 5 & Sap \\
\hline 47 & 48.3 & $\begin{array}{l}\text { Procyanidin II } \\
\text { Derivative }\end{array}$ & 563.1567 & $\mathrm{C}_{30} \mathrm{H}_{26} \mathrm{O}_{11}$ & 3 & Sap \\
\hline 48 & 50.0 & $\begin{array}{c}\text { Procyanidin II } \\
\text { Derivative }\end{array}$ & 563.1561 & $\mathrm{C}_{30} \mathrm{H}_{26} \mathrm{O}_{11}$ & 2 & Sap \\
\hline 49 & 50.6 & Unknown & 153.0538 & - & & Sap \\
\hline 50 & 51.1 & Flavanonol Derivative & 333.0974 & $\mathrm{C}_{17} \mathrm{H}_{16} \mathrm{O}_{7}$ & 1 & Sap \\
\hline 51 & 51.3 & Flavanonol Derivative & $\begin{array}{l}305.0666 \\
305.0667\end{array}$ & $\mathrm{C}_{15} \mathrm{H}_{12} \mathrm{O}_{7}$ & $\begin{array}{l}2 \\
2\end{array}$ & $\begin{array}{c}\text { Sap } \\
\text { Stem bark }\end{array}$ \\
\hline 52 & 51.6 & Flavonoid Derivative & $\begin{array}{l}287.0551 \\
287.0550\end{array}$ & $\mathrm{C}_{15} \mathrm{H}_{10} \mathrm{O}_{6}$ & $\begin{array}{l}2 \\
2\end{array}$ & $\begin{array}{c}\text { Sap } \\
\text { Stem bark }\end{array}$ \\
\hline 53 & 51.7 & $\begin{array}{l}\text { Procyanidin II } \\
\text { Derivative }\end{array}$ & 563.1555 & $\mathrm{C}_{30} \mathrm{H}_{26} \mathrm{O}_{11}$ & 1 & Sap \\
\hline 54 & 51.7 & Flavonoid Derivative & 331.0823 & $\mathrm{C}_{17} \mathrm{H}_{14} \mathrm{O}_{7}$ & 2 & Sap \\
\hline 55 & 51.8 & $\begin{array}{l}\text { Flavan-3-ol } \\
\text { Derivative }\end{array}$ & 305.1011 & $\mathrm{C}_{16} \mathrm{H}_{16} \mathrm{O}_{6}$ & 5 & Sap \\
\hline 56 & 52.0 & Flavonoid Derivative & 301.0709 & $\mathrm{C}_{16} \mathrm{H}_{12} \mathrm{O}_{6}$ & 2 & Sap \\
\hline 57 & 52.1 & Flavanonol Derivative & 319.0818 & $\mathrm{C}_{16} \mathrm{H}_{14} \mathrm{O}_{7}$ & 1 & Sap \\
\hline 58 & 52.2 & Flavone Derivative & 345.0979 & $\mathrm{C}_{18} \mathrm{H}_{16} \mathrm{O}_{7}$ & 2 & Sap \\
\hline 59 & 52.4 & Quercetin & 303.0513 & $\mathrm{C}_{15} \mathrm{H}_{10} \mathrm{O}_{7}$ & 3 & Sap \\
\hline 60 & 52.4 & Flavone Derivative & $\begin{array}{l}373.1287 \\
373.1289\end{array}$ & $\mathrm{C}_{20} \mathrm{H}_{20} \mathrm{O}_{7}$ & $\begin{array}{l}1 \\
1\end{array}$ & $\begin{array}{c}\text { Sap } \\
\text { Stem bark }\end{array}$ \\
\hline 61 & 52.8 & Unknown & 305.2480 & $\mathrm{C}_{20} \mathrm{H}_{32} \mathrm{O}_{2}$ & 1 & Sap \\
\hline 63 & 53.8 & Unknown & 192.1406 & - & & Stem bark \\
\hline
\end{tabular}

samples. Commercial and stem bark sample are similar in the composition mainly by the presence of catechin, epicatechin, and procyanidin derivatives, while the presence of flavonoids as quercetin distinguishes the sap from both species (Figures 3(b) and 4). The present study demonstrates a simple and efficient method for the screening of the counterfeiting of commercial samples of jatobá that should be based on the presence of flavonoids derivatives and low level of procyanidins.

The counterfeiting of the jatobá sap found in this study is possibly related to the difficulty in obtaining this vegetal material, which, besides being produced for only a few months of the year by the plant, as reported by local merchants, is difficult to obtain and can be acquired only when the trunk tree exudes the sap. The simplicity of its production through the decoction of the bark and its reddish color similar to the sap favors the counterfeiting of these samples for the market. This study demonstrates that these two products have a different composition of secondary metabolites, which may result in the absence of the expected effects, yet still bringing side effects to the patient.

Five out of six commercial samples were microbiologically contaminated. Fourteen microorganisms were isolated, eight of which were bacteria (four Enterobacter spp., three 

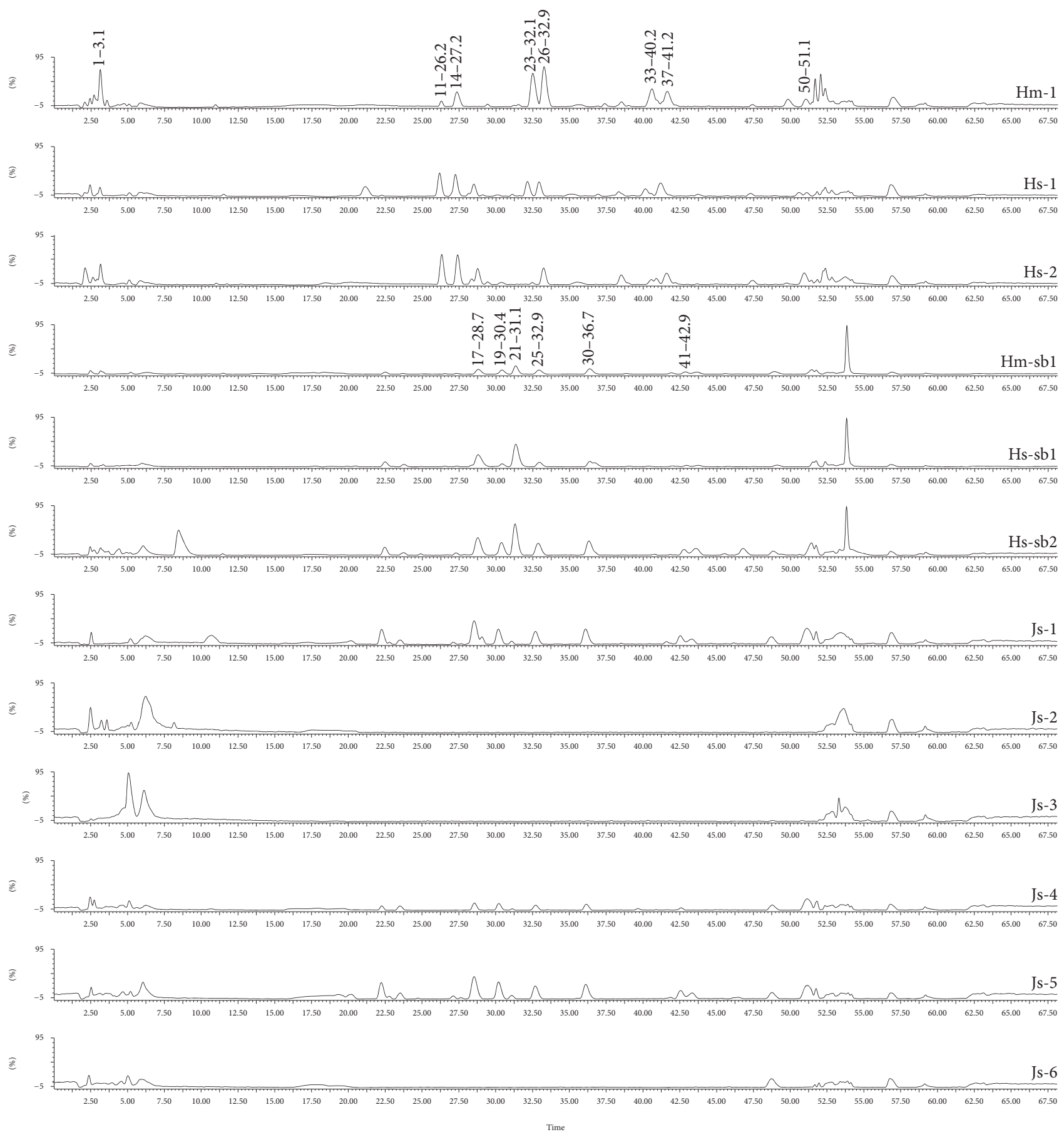

FIGURE 2: Chromatograms obtained using HPLC-MS of the control sap, Hm-1, Hs-1, and Hs-2 of the bark decoctions Hm-sb1, Hs-sb1, and Hs-sb2, and of the commercial samples Js-1 to Js-6. The samples Hm-1 and Hm-sb1 belong to H. martiana and Hs-1, Hs-2, Hs-sb1, and Hs-sb2 to H. stigonocarpa. The main peaks of the sap and stem bark are also shown in the chromatogram. Table 2 shows detailed information about the peaks.

Klebsiella spp., and one Bacillus sp.) and six were fungi (four Candida spp., one Rhodotorula sp., and one Sporobolomyces salmonicolor). Four of the five positive cultured saps contained two or more microorganisms within the same sample (Table 3). Microbial contamination was considered high, ranging from 1,700 to $100,000 \mathrm{CFU} / \mathrm{mL}$ of the sap.
It has already been established throughout the referential literature that medicinal herbs usually contain bacteria and fungi in their constitution, originating from soil or present in their natural microflora [25]. For the analysis of the CFUs obtained from plant material, the limits set by the Pharmacopeia take into consideration such intrinsic microflora. 


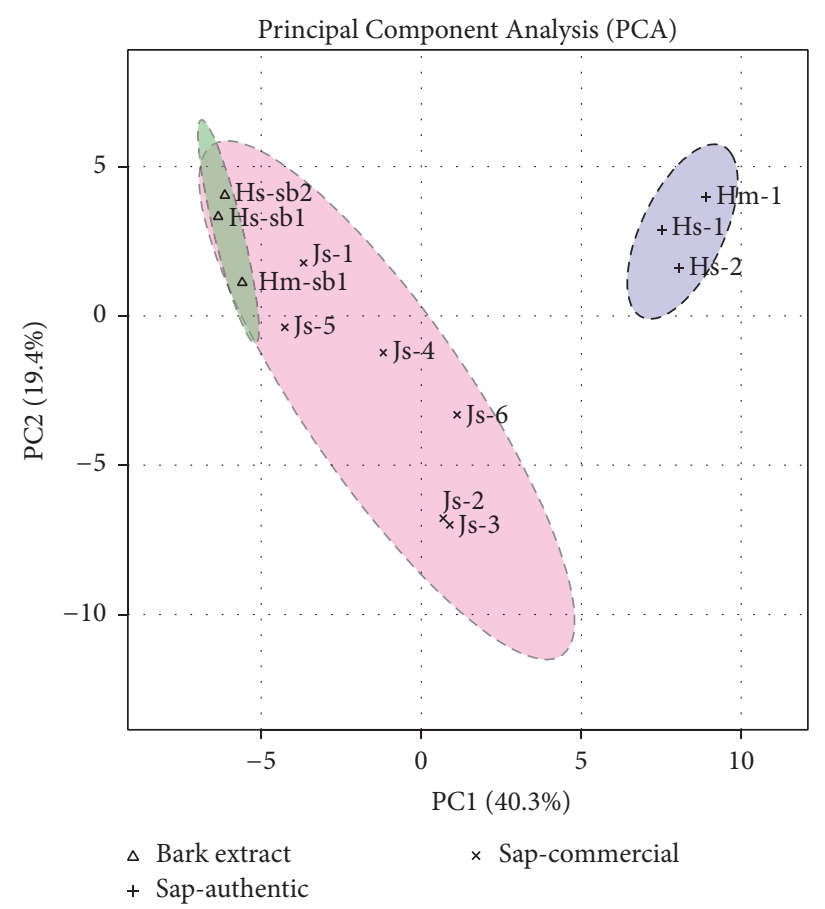

(a)

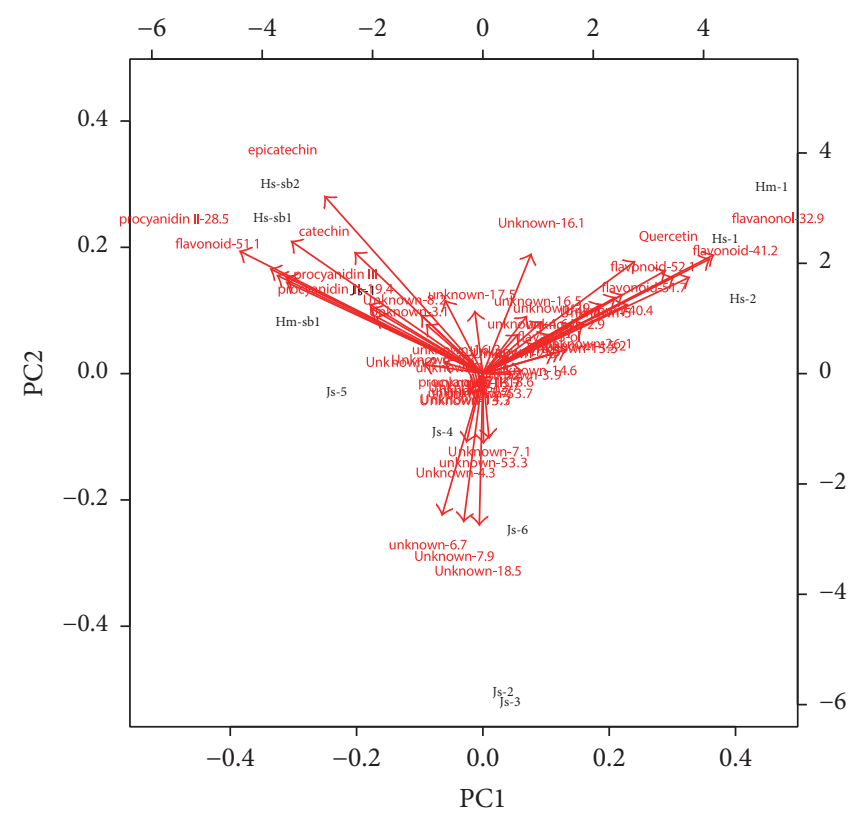

(b)

Figure 3: (a) Principal Component Analysis (PCA) and (b) Biplot of loadings and samples. Js-1 to Js-6 (commercial samples), Hm-1, Hs-1, and Hs-2 (authentic jatobá sap), and Hm-sb1, Hs-sb1, and Hs-sb2 (bark decoctions). The samples Hm-1 and Hm-sb1 belong to H. martiana and Hs-1, Hs-2, Hs-sb1, and Hs-sb2 to H. stigonocarpa. Ellipses represent 95\% confidence area around the groups.

According to the World Health Organization [25] plants consumed by the population must be free of Salmonella sp., Escherichia coli $(<10 \mathrm{CFU})$, other species of Enterobacteriaceae $\left(<10^{3} \mathrm{CFU}\right)$, and of yeasts and molds $\left(<10^{3} \mathrm{CFU}\right)$.

Despite the absence of Salmonella sp. and Escherichia coli, the isolation of other enterobacteria such as Enterobacter spp. and Klebsiella spp. may suggest additional fecal contamination. The lack of hygiene in handling commercial sap may have favored the isolation of these microorganisms. Previous studies have reported that hygiene standards must be established during the cultivation and harvesting of the plant species to avoid cross-contamination [34]. The liquid form of the jatobá sap and its maintenance at room temperature during storage favored the multiplication of microorganisms.

Microbial growth was also observed in Hs-1 (control sample); however, it was considered low in number (of $200 \mathrm{CFU}$ ). The bacteria were found to belong to the genus Bacillus, which, except $B$. anthracis and B. cereus both of which are pathogenic and were not found in this sample, are considered to be environmental contaminants [24].

To summarize, the microbiological contamination found in this study was higher than that permitted by the World Health Organization, making the samples unfit for consumption.

Thus, we issue a warning with regard to the adoption of stricter measures of quality control, from the acquisition of the sap until it is offered for sale. Folk wisdom alone cannot be considered as the single criterion for the consumption of medicinal plants [30].
Another essential factor in the safe use of jatobá sap is the evaluation of toxicity. A plant species exhibiting toxicity can trigger tissue damage to vital organs, causing death in extreme cases due mainly to its low therapeutic index. Thus the toxicity test is an essential step during the analysis of natural products [35].

During the acute toxicity test of the jatobá sap, death was not observed in any of the animals. As for systemic behavioral observations relating to toxicity, except for urinary output, the parameters were considered to be normal and remained unchanged throughout the experiment. No impact on the consciousness of animals or change in general activity or motor coordination, reflexes, or any activity related to the central or autonomous nervous system, indicative of toxicity, was observed. The consumption of food and water was monitored over 14 days and remained without significant change.

The weight of the animals did not change significantly throughout the test. Its observation also can be applied to the relative weights of the kidney and liver after euthanasia when compared to the control group. It is common to find weight change as being a manifestation of toxicity [36].

The hematological and biochemical rates in the treated rats are significantly affected when exposed to potentially toxic compounds [37], and the results obtained, except glucose levels, showed no significant difference (Table 4).

For the acute and subacute toxicity evaluations performed on the leaf extract of Herniaria glabra, researchers found a significant decrease in glucose levels of $30 \%$ in normoglycemic rats and reported that new studies are being 


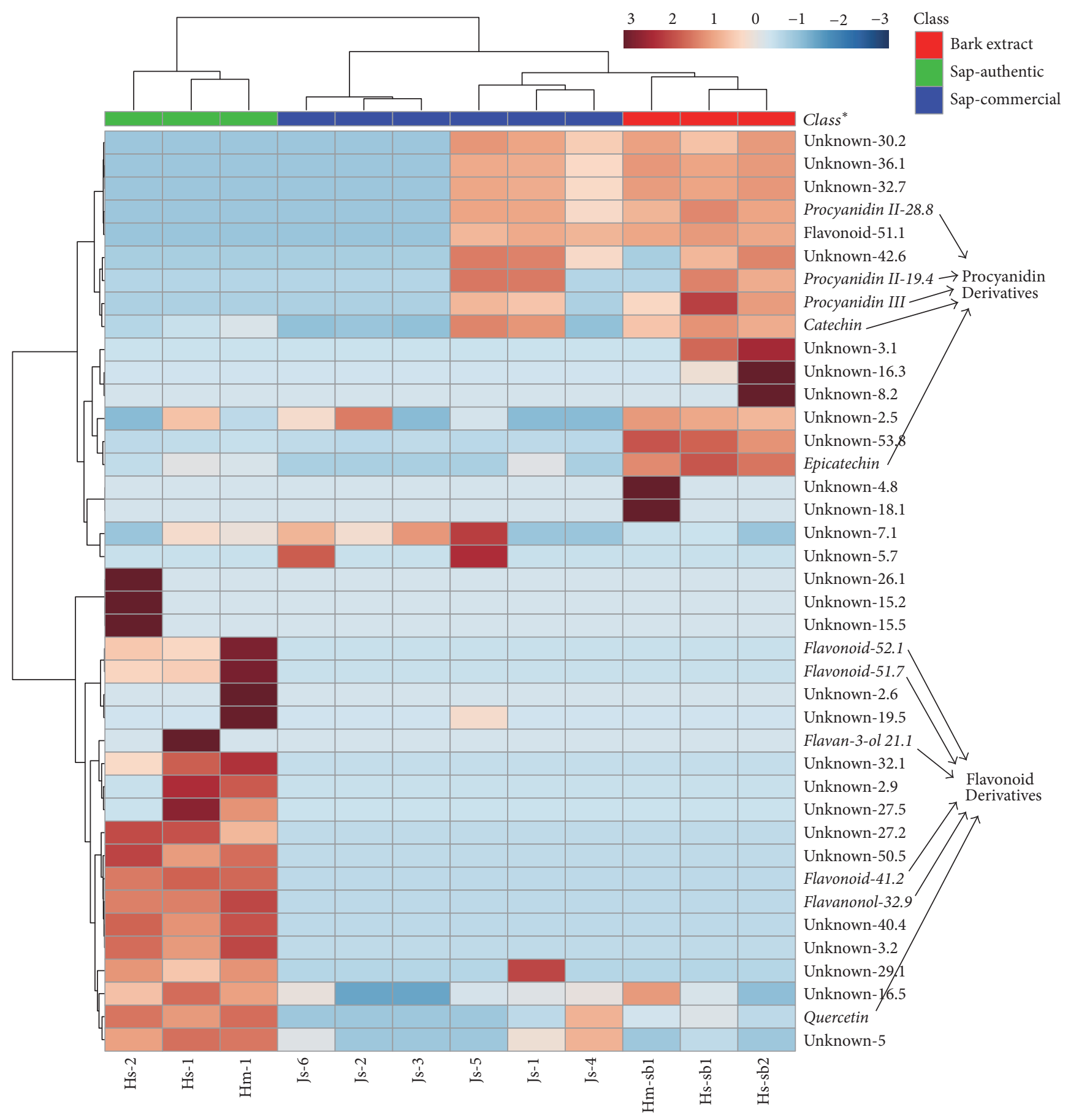

FIgURE 4: Heatmap of peaks from jatobá sap samples. The legend on the superior part indicates the class of the sample. The legend on the bottom indicates the sample identification (Table 1). The values have been log transformed and hierarchical clustering was organized using Euclidean distance, Ward clustering algorithm, and the top 40 metabolites selected by ANOVA $(p \leq 0.05)$. Red color indicates higher concentration; blue color indicates lower concentration. ${ }^{*}$ More details about the compounds shown in the right border can be found in Table 2.

developed in order to determine the hypoglycemic activity of extracts of this plant in a standard test performed on diabetic rats [38]. In this work, as shown in Table 4, when compared to the control group, the groups treated with Hs-1 significantly decrease the rate of glucose in $43 \%$ when compared to the normoglycemic rats. This change may indicate a hypoglycemic potential of the plant sample.

It was also observed that the treated rats decreased the frequency of urination throughout the experiment after the administration of the sap by gavage. The control group 
TABLE 3: Identification of bacteria and fungi present in the commercial samples (Js-1 to Js-6) and control sap (Hs-1).

\begin{tabular}{lccc}
\hline Sample & Growth & Morphology & Identification \\
\hline Js-1 & $2,550 \mathrm{CFU} \pm 220$ & GPB & Bacillus sp. \\
Js-1 & $2,200 \mathrm{CFU} \pm 500$ & Yeast & Candida lusitaniae \\
Js-3 & $\geq 100,000 \mathrm{CFU}$ & GNB & Enterobacter gergoviae \\
Js-3 & $\geq 100,000 \mathrm{CFU}$ & $\mathrm{GNB}$ & Klebsiella oxytoca \\
Js-3 & $1,700 \mathrm{CFU} \pm 60$ & Yeast & Candida albicans \\
Js-3 & $34,000 \mathrm{CFU} \pm 300$ & Yeast & Rhodotorula sp. \\
Js-4 & $\geq 100,000 \mathrm{CFU}$ & GNB & Enterobacter gergoviae \\
Js-4 & $\geq 100,000 \mathrm{CFU}$ & GNB & Klebsiella oxytoca \\
Js-4 & $55,000 \mathrm{CFU} \pm 500$ & Yeast & Yeast \\
Js-4 & $\geq 100,000 \mathrm{CFU}$ & GNB & Sporobolomyces salmonicolor \\
Js-5 & $61,100 \mathrm{CFU} \pm 1100$ & GNB & Candida tropicalis \\
Js-5 & $11,900 \mathrm{CFU} \pm 570$ & Yeast & Enterobacter cloacae \\
Js-5 & $\geq 100,000 \mathrm{CFU}$ & GNB & Klebsiella oxytoca \\
Js-6 & $61,000 \mathrm{UFC} \pm 800$ & GPB & Candida tropicalis \\
Hs-1 & $200 \mathrm{UFC} \pm 40$ & Enterobacter agglomerans \\
\hline
\end{tabular}

GPB: Gram positive bacilli; GNB: Gram negative bacilli; CFU: colony forming unit.

TABLE 4: Haematological and biochemical parameters of rats treated with the sap of the H. stigonocarpa (Hs-1).

(a)

\begin{tabular}{lcccc}
\hline Haematological parameters & Control $(\mathrm{n}=5)$ & T1 $(\mathrm{n}=9)$ & T2 $(\mathrm{n}=9)$ & T3 $(\mathrm{n}=12)$ \\
\hline RBC $\left(10^{6} / \mathrm{Mm}^{3}\right)$ & $7.858 \pm 0.28$ & $8.45 \pm 0.72$ & $8.19 \pm 0.51$ & $8.47 \pm 0.54$ \\
Hemoglobin $(\mathrm{g} / \mathrm{dL})$ & $14.54 \pm 0.38$ & $15.44 \pm 1.24$ & $15.07 \pm 0.77$ & $15.39 \pm 0.91$ \\
Hematocrit $(\%)$ & $45.04 \pm 1.48$ & $49.81 \pm 5.35$ & $47.58 \pm 2.69$ & $49.75 \pm 3.05$ \\
MCV $(\mathrm{fL})$ & $57.36 \pm 1.86$ & $58.98 \pm 3.99$ & $58.13 \pm 1.54$ & $58.77 \pm 2.27$ \\
MCH $(\mathrm{pg})$ & $18.52 \pm 0.31$ & $18.31 \pm 0.64$ & $18.41 \pm 0.69$ & $18.17 \pm 0.44$ \\
MCHC $(\mathrm{g} / \mathrm{dL})$ & $32.3 \pm 0.67$ & $31.09 \pm 1.51$ & $31.70 \pm 1.07$ & $30.96 \pm 0.89$ \\
Platelets $\left(10^{3} / \mathrm{Mm}^{3}\right)$ & $489.8 \pm 102.83$ & $603.56 \pm 151.58$ & $557.33 \pm 71.77$ & $593.92 \pm 173.49$ \\
Leukocytes $\left(10^{3} / \mathrm{Mm}^{3}\right)$ & $7.68 \pm 2$ & $10.06 \pm 4.44$ & $9.45 \pm 1.75$ & $9.56 \pm 4.40$ \\
Neutrophils $(\%)$ & $22.4 \pm 5.8$ & $16.78 \pm 4.61$ & $14.70 \pm 3.47$ & $79.29 \pm 5.59$ \\
Lymphocytes $(\%)$ & $72.45 \pm 9.21$ & $76.98 \pm 5.22$ & $4.35 \pm 2.47$ & $80.63 \pm 6$ \\
Monocytes $(\%)$ & $3.02 \pm 1.52$ & $4.02 \pm 2.02$ & $1.03 \pm 0.57$ & $3.63 \pm 2.81$ \\
Eosinophils $(\%)$ & $2 \pm 3.60$ & $1.67 \pm 2.02$ & $0.61 \pm 0.34$ & $1.02 \pm 0.43$ \\
Basophils $(\%)$ & $0.12 \pm 0.09$ & $0.56 \pm 0.64$ & & $0.65 \pm 0.39$ \\
\hline
\end{tabular}

(b)

\begin{tabular}{lcccc}
\hline Biochemical parameters & Control $(\mathrm{n}=8)$ & T1 $(\mathrm{n}=12)$ & T2 $(\mathrm{n}=12)$ & T3 $(\mathrm{n}=10)$ \\
\hline Urea $(\mathrm{mg} / \mathrm{dL})$ & $47 \pm 6.48$ & $49.33 \pm 5.82$ & $46.25 \pm 4.67$ & $51 \pm 6.80$ \\
Creatinine (mg/dL) & $0.4 \pm 0.06$ & $0.47 \pm 0.12$ & $0.45 \pm 0.05$ & $0.42 \pm 0.04$ \\
Amylase (U/L) & $2360 \pm 375.14$ & $342.67 \pm 305.27$ & $2376.92 \pm 235$ & $2374.80 \pm 451.59$ \\
Lipase (U/L) & $5.75 \pm 0.31$ & $6.53 \pm 0.69$ & $6.46 \pm 0.68$ & $6.28 \pm 0.37$ \\
AST (U/L) & $135.5 \pm 90.01$ & $185.42 \pm 107.29$ & $159.17 \pm 79.26$ & $115 \pm 38.11$ \\
ALT (U/L) & $40.5 \pm 15.92$ & $63.92 \pm 13.64$ & $63.58 \pm 23.04$ & $47.60 \pm 10.90$ \\
Glucose (mg/dL) & $269 \pm 57.28$ & $157 \pm 34.03^{* * *}$ & $162.75 \pm 62.17^{* * *}$ & $139 \pm 36.45^{* * *}$ \\
\hline
\end{tabular}

Data expressed as mean average \pm standard deviation. Control: rats treated with water T1: dose of $1000 \mathrm{mg} / \mathrm{kg}$, T2: dose of $2500 \mathrm{mg} / \mathrm{kg}$, and T3: dose of $5000 \mathrm{mg} / \mathrm{kg}$ of the sap of the Hymenaea stigonocarpa (Hs-1). MCV: mean corpuscular volume, MCH: mean corpuscular haemoglobin, MCHC: mean corpuscular haemoglobin concentration, ALT: alanine aminotransferase, and AST: aspartate aminotransferase. ${ }^{* * *} p \leq 0.001$ (compared with the control group). 


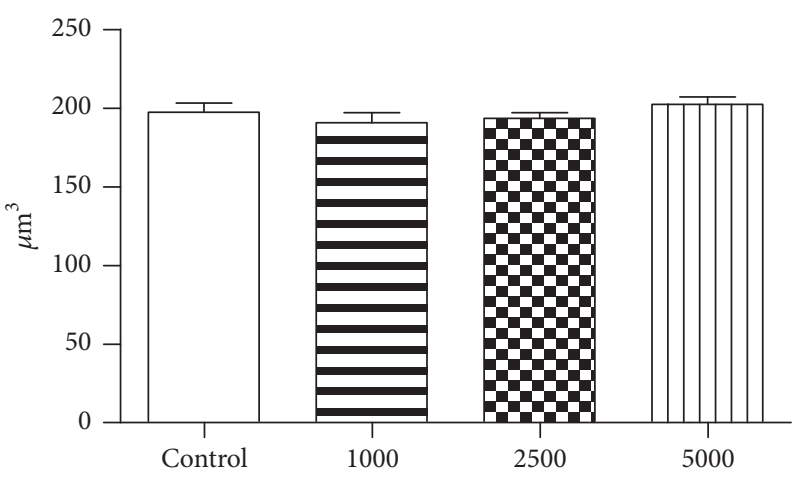

(a)

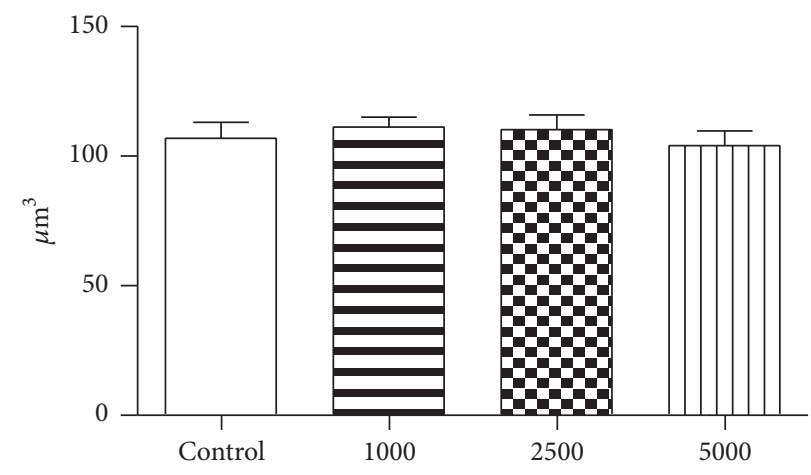

(c)

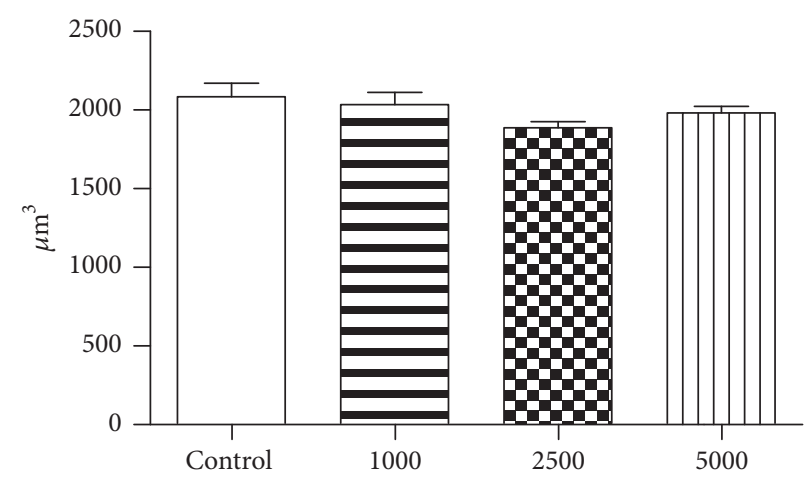

(b)

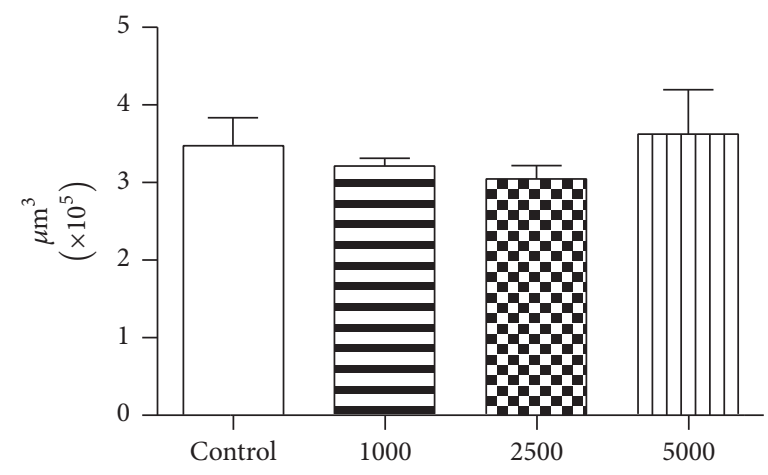

(d)

Figure 5: Results expressed by ANOVA followed by the Tukey test. (a) Nuclear volume of hepatocytes. (b) Cell volume of hepatocytes. (c) Cell volume of the proximal convoluted tubule. (d) Volume of the renal glomerulus. Control: rats injected with water; 1000: dose of 1000 mg/kg; 2500: dose of $2500 \mathrm{mg} / \mathrm{kg}$; and 5000: dose of $5000 \mathrm{mg} / \mathrm{kg}$ of H. stigonocarpa (Hs-1). Values expressed as mean of volume \pm error according to average standards.

showed an average of $1.760 \pm 1.46$ wells during the 14 days of the experiment; the group treated with a $1000 \mathrm{mg} / \mathrm{kg}$ dose showed an average frequency of 0.489 wells $\pm 0.32(p<0.001)$ and more concentrated doses, $0.323 \pm 0.24$ and $0.214 \pm 0.44$ for $2500 \mathrm{mg} / \mathrm{kg}$ and $5000 \mathrm{mg} / \mathrm{kg}$, respectively $(p<0.0001)$, compared with the control group.

The decrease in diuresis may be associated with the decreased of glucose levels, taking into account the fact that hyperglycemia causes a phenomenon known as polyuria (increased urination) and is accentuated due to osmotic diuresis caused by high concentration of glucose in plasma [39]. As the jatobá sap decreased the rate of glucose in normoglycemic rats, the opposite effect could have been accentuated, had the plasma glucose concentration rates been lower.

Regarding the histopathological analysis, no changes in cell structure or any leukocyte infiltration, sinusoidal congestion, or small fat droplets were observed. Quantitatively there were no morphological changes (Figure 5), and the rates of ALT and AST remained unchanged (Table 4).

The kidney, another target for numerous toxic substances, which exhibits a high rate of perfusion and ability to focus on several compounds in the tubular lumen [36], macroscopically showed no renal disorder in this study. There was no difference in the relative weight of the organ, and the morphometric analysis showed no change in nuclear volume of the proximal convoluted tubule and the diameter of the glomerulus (Figure 5), suggesting that tissue integrity of the kidney was preserved and creatinine and urea rates confirmed this observation (Table 4).

The present study demonstrated that $83.3 \%$ of samples were considered unsuitable for consumption. The methods used to analyze the authenticity were effective, and the results revealed that none of the commercial samples were obtained from authentic jatobá sap, probably achieved by a decoction of the stem bark or other sources. The commercial samples showed a high microbial contamination and acute toxicity analysis of an authentic sample showed no signs of toxicity and no histological changes in the liver and kidney tissue.

Finally, the evaluated commercial samples do not meet the minimum quality criteria for consumption and may present a danger to people. Therefore, this is an alert to the supervising authorities, to search for new methodologies and ways of implementing more efficient measures to ensure the safety of the population.

\section{Competing Interests}

The authors declare that there are no competing interests regarding the publication of this paper. 


\section{Acknowledgments}

The authors express their gratitude to Professor Dr. Norberto Peporine Lopes for his collaboration in this research, CNPq (Conselho Nacional de Desenvolvimento Científico e Tecnológico), FUNDECT (Fundação de Apoio ao Desenvolvimento do Ensino, Ciência e Tecnologia do Estado de Mato Grosso do Sul), and INAU (Instituto Nacional de Áreas Úmidas) for their support in carrying out the study.

\section{References}

[1] J. M. Monteiro, M. A. Ramos, E. D. L. Araújo, E. L. C. Amorim, and U. P. Albuquerque, "Dynamics of medicinal plants knowledge and commerce in an urban ecosystem (Pernambuco, Northeast Brazil)," Environmental Monitoring and Assessment, vol. 178, no. 1, pp. 179-202, 2011.

[2] F. Firenzuoli and L. Gori, "Herbal medicine today: clinical and research issues," Evidence-based Complementary and Alternative Medicine, vol. 4, S1, pp. 37-40, 2007.

[3] M. Zaroni, R. Pontarolo, W. Abrahão, M. Fávero, C. Correa Júnior, and D. Stremel, "Qualidade microbiológica das plantas medicinais produzidas no Estado do Paraná," Revista Brasileira de Farmacognosia, vol. 14, no. 1, pp. 29-39, 2004.

[4] F. C. Alvarenga, E. d. Garcia, E. M. Bastos, T. S. Grandi, and M. G. Duarte, "Avaliação da qualidade de amostras comerciais de folhas e tinturas de guaco," Revista Brasileira de Farmacognosia, vol. 19, no. 2a, pp. 442-448, 2009.

[5] M. Garg and J. Singh, "Quantitative AAS stimation of heavy metals and trace elements in marketed ayurvedic churna preparations in India," International Journal of Pharmaceutical Sciences and Research, vol. 3, pp. 1331-1336, 2012.

[6] S. K. Sagoo, C. L. Little, M. Greenwood et al., "Assessment of the microbiological safety of dried spices and herbs from production and retail premises in the United Kingdom," Food Microbiology, vol. 26, no. 1, pp. 39-43, 2009.

[7] V. F. Veiga Jr., A. C. Pinto, and M. A. M. Maciel, "Medicinal plants: safe cure?” Quimica Nova, vol. 28, no. 3, pp. 519-528, 2005.

[8] C. S. J. Woo, J. S. H. Lau, and H. El-Nezami, "Herbal medicine. Toxicity and recent trends in assessing their potential toxic effects," Advances in Botanical Research, vol. 62, pp. 365-384, 2012.

[9] P. Vichova and L. Jahodar, "Plant poisonings in children in the Czech Republic, 1996-2001," Human and Experimental Toxicology, vol. 22, no. 9, pp. 467-472, 2003.

[10] A. C. S. Ramos, J. P. de Lemos-Filho, and M. B. Lovato, "Phylogeographical structure of the neotropical forest tree Hymenaea courbaril (Leguminosae: Caesalpinioideae) and its relationship with the vicariant Hymenaea stigonocarpa from Cerrado," Journal of Heredity, vol. 100, no. 2, pp. 206-216, 2009.

[11] M. F. Agra, G. S. Baracho, K. Nurit, I. J. L. D. Basílio, and V. P. M. Coelho, "Medicinal and poisonous diversity of the flora of 'Cariri Paraibano', Brazil," Journal of Ethnopharmacology, vol. 111, no. 2, pp. 383-395, 2007.

[12] L. R. S. Gazzaneo, R. F. Paiva de Lucena, and U. P. de Albuquerque, "Knowledge and use of medicinal plants by local specialists in an region of Atlantic Forest in the state of Pernambuco (Northeastern Brazil)," Journal of Ethnobiology and Ethnomedicine, vol. 1, article no. 9, 2005.
[13] T. S. Grandi, J. A. Trindade, M. J. Pinto, L. L. Ferreira, and A. C. Catella, "Plantas medicinais de Minas Gerais, Brasil," Acta Botanica Brasilica, vol. 3, no. 2, pp. 185-224, 1989.

[14] F. R. Mendes and E. A. Carlini, "Brazilian plants as possible adaptogens: an ethnopharmacological survey of books edited in Brazil," Journal of Ethnopharmacology, vol. 109, no. 3, pp. 493500, 2007.

[15] G. S. Hirschmann and A. R. de Arias, "A survey of medicinal plants of Minas Gerais, Brazil," Journal of Ethnopharmacology, vol. 29, no. 2, pp. 159-172, 1990.

[16] P. R. Orsi, F. Bonamin, J. A. Severi et al., "Hymenaea stigonocarpa Mart. ex Hayne: a Brazilian medicinal plant with gastric and duodenal anti-ulcer and antidiarrheal effects in experimental rodent models," Journal of Ethnopharmacology, vol. 143, no. 1, pp. 81-90, 2012.

[17] C. A. Maranhão, I. O. Pinheiro, A. L. B. D. Santana, L. S. Oliveira, M. S. Nascimento, and L. W. Bieber, "Antitermitic and antioxidant activities of heartwood extracts and main flavonoids of Hymenaea stigonocarpa Mart.," International Biodeterioration and Biodegradation, vol. 79, pp. 9-13, 2013.

[18] M. T. Doménech-Carbó, J. de la Cruz-Cañizares, L. Osete-Cortina, A. Doménech-Carbó, and H. David, "Ageing behaviour and analytical characterization of the Jatobá resin collected from Hymenaea stigonocarpa Mart," International Journal of Mass Spectrometry, vol. 284, no. 1-3, pp. 81-92, 2009.

[19] M. E. G. D. C. Silva, A. L. Guimarães, A. P. de Oliveira et al., "HPLC-DAD analysis and antioxidant activity of Hymenaea martiana Hayne (Fabaceae)," Journal of Chemical and Pharmaceutical Research, vol. 4, no. 2, pp. 1160-1166, 2012.

[20] M. C. A. Neves, P. C. A. Neves, J. C. Zanini Jr., Y. S. Medeiros, R. A. Yunes, and J. B. Calixto, "Analgesic and anti-inflammatory activities of the crude hydroalcoholic extract obtained from the bark of Hymenaea martiana," Phytotherapy Research, vol. 7, no. 5, pp. 356-362, 1993.

[21] A. C. M. De Souza, L. Kato, C. C. Da Silva, A. F. Cidade, C. M. A. De Oliveira, and M. D. R. R. Silva, "Antimicrobial activity of Hymenaea martiana towards dermatophytes and Cryptococcus neoformans," Mycoses, vol. 53, no. 6, pp. 500-503, 2010.

[22] C. R. Vale, C. R. Silva, C. M. A. Oliveira, A. L. Silva, S. Carvalho, and L. Chen-Chen, "Assessment of toxic, genotoxic, antigenotoxic, and recombinogenic activities of Hymenaea courbaril (Fabaceae) in Drosophila melanogaster and mice," Genetics and Molecular Research, vol. 12, no. 3, pp. 2712-2724, 2013.

[23] The United States Pharmacopeial Convention, United States Pharmacopeia, The United States Pharmacopeial Convention, Rockville, Md, USA, 2009.

[24] E. W. Koneman, S. D. Allen, W. M. Janda et al., Diagnóstico Microbiológico: Texto e Atlas Colorido, Guanabara Koogan, Rio de Janeiro, Brazil, 2008.

[25] WHO, Quality Control Methods for Medicinal Plant Materials, World Health Organization, Geneva, Switzerland, 1998.

[26] OECD, Guidelines for the Testing of Chemicals, OECD 423. Acute Oral Toxicity-Acute Toxic Class Method, Organisation for Economic Cooperation and Development, Paris, France, 2001.

[27] Guia para a Condução de Estudos não Clínicos de Segurança Necessário ao Desenvolvimento de Medicamentos, Edited by ANVISA, Gerência de Avaliação de Segurança e EficáciaGESEF, Brasília, Brazil, 2010.

[28] A. L. Cunha-Laura, R. J. Oliveira, A. L. C. de Barros, J. M. de Siqueira, M. do Carmo Vieira, and S. A. Auharek, "Maternal exposure to Cochlospermum regium: a toxicological evaluation," Brazilian Journal of Pharmacognosy, vol. 23, no. 2, pp. 374-378, 2013. 
[29] W. Gao, H. Yang, L.-W. Qi et al., "Unbiased metabolite profiling by liquid chromatography-quadrupole time-of-flight mass spectrometry and multivariate data analysis for herbal authentication: classification of seven Lonicera species flower buds," Journal of Chromatography A, vol. 1245, pp. 109-116, 2012.

[30] H. A. Gad, S. H. El-Ahmady, M. I. Abou-Shoer, and M. M. AlAzizi, "Application of chemometrics in authentication of herbal medicines: a review," Phytochemical Analysis, vol. 24, no. 1, pp. 1-24, 2013.

[31] P. Pothavorn, K. Kitdamrongsont, S. Swangpol et al., "Sap phytochemical compositions of some bananas in Thailand," Journal of Agricultural and Food Chemistry, vol. 58, no. 15, pp. 8782-8787, 2010.

[32] J.-H. Kim, E.-J. Doh, and G. Lee, "Evaluation of medicinal categorization of Atractylodes japonica koidz. by using internal transcribed spacer sequencing analysis and HPLC fingerprinting combined with statistical tools," Evidence-Based Complementary and Alternative Medicine, vol. 2016, Article ID 2926819, 12 pages, 2016.

[33] K. Sasaki, Y. Matsukura, K. Shijima, M. Miyake, D. Fujiwara, and Y. Konishi, "High-performance liquid chromatographic purification of oligomeric procyanidins, trimers up to nonamers, derived from the bark of Jatoba (Hymenaea courbaril)," Bioscience, Biotechnology and Biochemistry, vol. 73, no. 6, pp. 1274-1279, 2009.

[34] E. Czech, W. Kneifel, and B. Kopp, "Microbiological status of commercially available medicinal herbal drugs-a screening study," Planta Medica, vol. 67, no. 3, pp. 263-269, 2001.

[35] J. Qu, S.-S. Yu, D. Du, and Y.-D. Wang, "Bioactive constituents from toxic seed plants in China," RSC Advances, vol. 3, no. 26, pp. 10078-10102, 2013.

[36] S. R. M. Grance, M. A. Teixeira, R. S. Leite et al., "Baccharis trimera: effect on hematological and biochemical parameters and hepatorenal evaluation in pregnant rats," Journal of Ethnopharmacology, vol. 117, no. 1, pp. 28-33, 2008.

[37] L. C. Cunha, F. S. Azeredo, A. C. V. Mendonça et al., "Acute and subacute toxicity studies of the latex and of the ethanolic extract of the leaves of Synadenium umbellatum Pax in rats," Brazilian Journal of Pharmacognosy, vol. 19, no. 2, pp. 403-411, 2009.

[38] H. Rhiouani, J. El-Hilaly, Z. H. Israili, and B. Lyoussi, "Acute and sub-chronic toxicity of an aqueous extract of the leaves of Herniaria glabra in rodents," Journal of Ethnopharmacology, vol. 118, no. 3, pp. 378-386, 2008.

[39] W. C. Dornas, T. T. De Oliveira, R. G. R. Dores, M. H. A. Fabres, and T. J. Nagem, "Antidiabetic effects of the medicinal plants," Brazilian Journal of Pharmacognosy, vol. 19, no. 2a, pp. 488-500, 2009. 


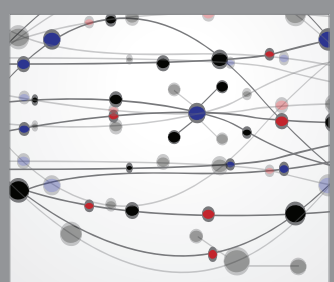

The Scientific World Journal
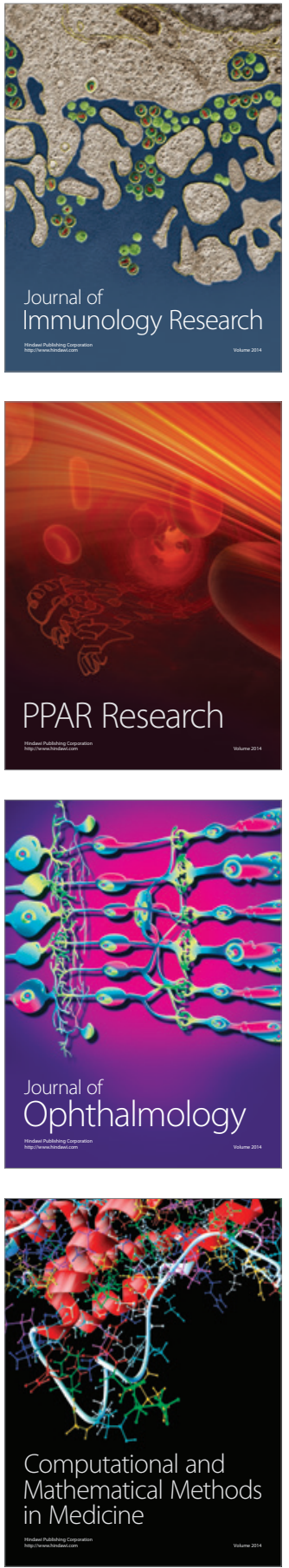

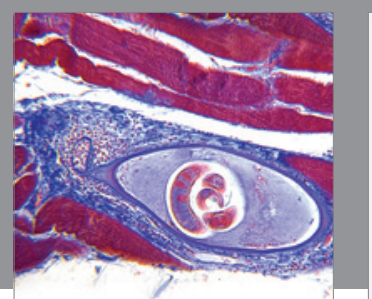

Gastroenterology Research and Practice
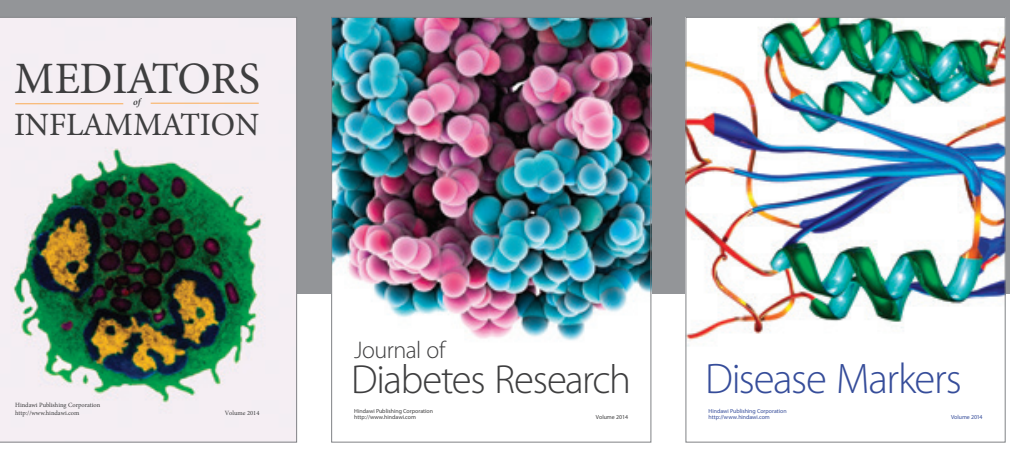

Disease Markers

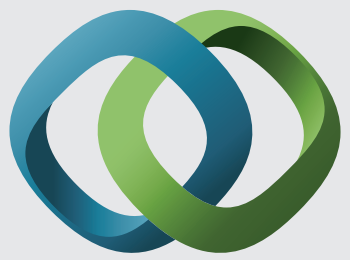

\section{Hindawi}

Submit your manuscripts at

https://www.hindawi.com
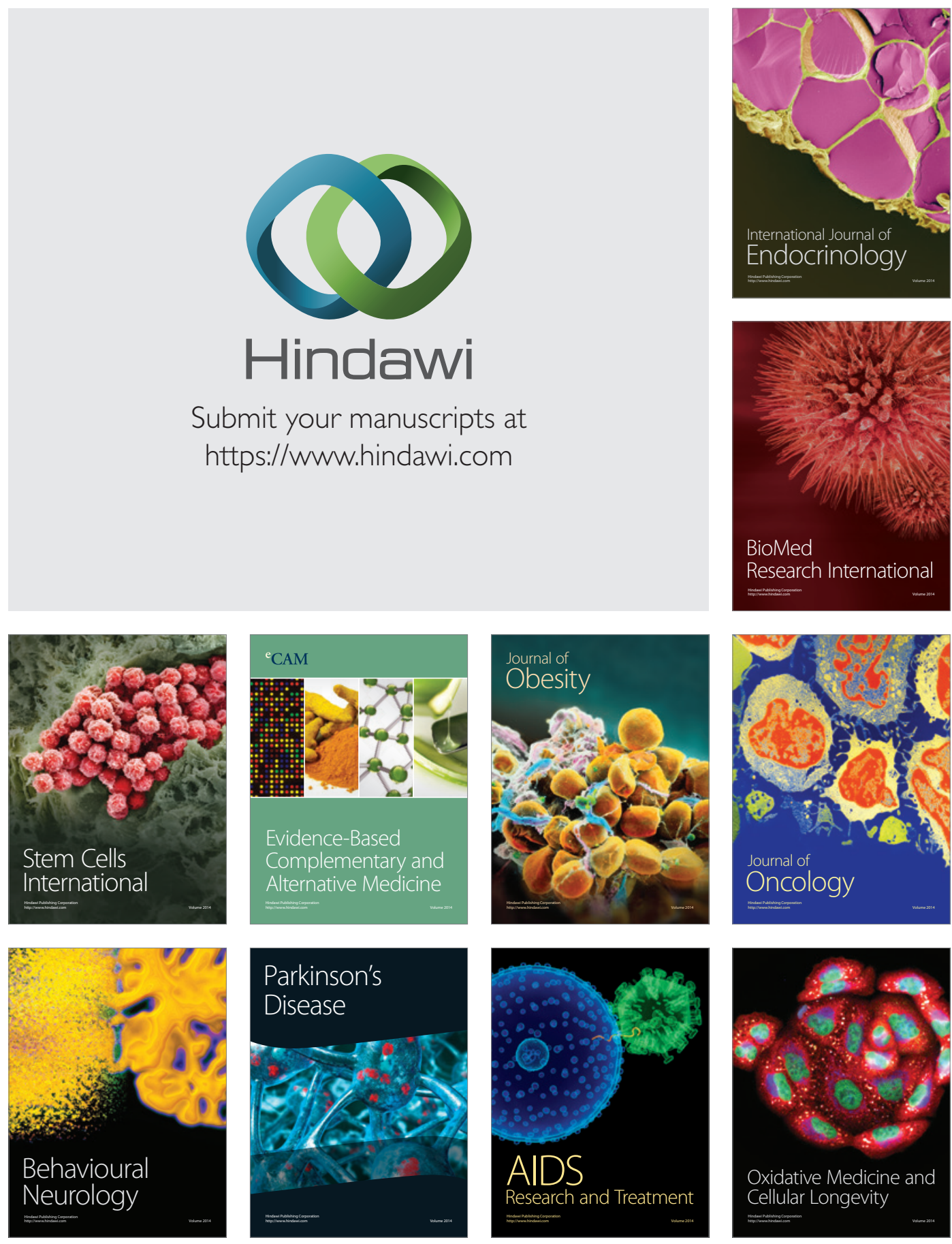